\title{
PENGARUH MODEL PEMBELAJARAN KOOPERATIF TIPE EVERYONE IS A TEACHER HERE TERHADAP HASIL BELAJAR SISWA PADA MATERI POKOK SISTEM REPRODUKSI \\ (Penelitian Quasi-experiment design di Kelas XI SMA Negeri Jatinangor)
}

\author{
Iis Yuniarti, Ara Hidayat dan Meti Maspupah \\ Program Studi Pendidikan Biologi, Program Sarjana S1, Universitas Islma Negeri \\ Sunan Gunung Djati Bandung
}

\begin{abstract}
Student learning outcomes in schools is often indicated with learning problems of these students in understanding the material. Indication is made possible because of the lack of effective student learning, even the students themselves do not feel motivated to follow in the classroom. In this research can help to overcome the existing problems, the implementation of cooperative learning model Everyone is a teacher here. The method used in this study is the method of Quasi-experimental design. The study design used was a nonequivalent control group pretest-posttest means researchers treated and make observations. Population taken is class XI Science. Data collection technique is done with the test. The research proves that learning model everyone is a teacher here can be a positive influence on learning outcomes of students in the subject matter of the reproductive system, with the average value of the posttest in the class that uses the model everyone is a teacher here 76.29 with both category and value gain 33,43 . In classes without a model the average posttest score 69.43 with enough categories and gain value 26.86. To test the hypothesis shows that $\mathrm{T}_{-}$hitung amounted to 2.38> T_tabel of 1.67 , so it can be concluded that the cooperative learning model everyone is a teacher here a positive effect on learning outcomes of students in the subject matter of the reproductive system.
\end{abstract}

Keyword: Everyone is a teacher here,Hasil Belajar, Sistem Reproduksi

\section{Pendahuluan}

Penilaian proses belajar adalah upaya memberi nilai terhadap kegiatan belajar-mengajar yang dilakukan oleh siswa dan guru dalam mencapai tujuan-tujuan dalam pengajaran. Dalam penilaian ini dilihat sejauh mana keefektifan dan efisiensinya dalam mencapai tujuan pengajaran atau perubahan tingkah laku siswa (Sudjana. 2012:3). Proses pendidikan menurut al-Quran adalah membaca, sebagaimana firman Allah SWT dalam surat Al-Alaq yaitu:

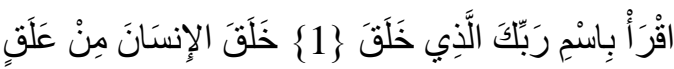

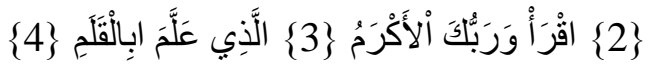

$$
\begin{aligned}
& \text { عَلَّمَ ألإنسنَانَ مَالَمْ يَعْ }
\end{aligned}
$$

Artinya : "Bacalah dengan (menyebut) nama Tuhanmu yang menciptakan (1), Dia telah menciptakan manusia dari segumpal darah (2), Bacalah! dan Tuhanmulah yang paling pemurah (3), yang mengajar (manusia) dengan kalam (4), dia 
mengajarkan kepada manusia apa yang tidak diketahuinya (5)"(Qs Al-Alaq:1-5). (Rohman. 2006:904-905)

Dalam proses pembelajaran, pengembangan kemampuan berkomunikasi yang baik dengan guru dan sesama siswa yang dilandasi sikap saling menghargai harus perlu secara terus menerus dikembangkan didalam setiap event pembelajaran (Aunurrahman. 2011:7)

Berdasarkan hasil wawancara dengan guru dan siswa diperoleh pembelajaran yang agak cenderung monoton, yaitu ceramah saja sehingga proses pembelajaran hanya berjalan satu arah. Hal ini menyebabkan siswa tidak termotivasi untuk belajar biologi. Belajar dengan model konvensional, siswa hanya menerima informasi yang kurang bermakna, sehingga banyak siswa yang menganggap biologi sebagai pelajaran hafalan. Seringkali guru menciptakan suasana pembelajaran yang tidak menyenangkan bagi siswa, guru banyak bercerita tanpa memperlihatkan siswa apakah sudah paham atau belum, yang penting bagi guru adalah materi tersebut sudah diajarkan.

Penilaian proses belajar adalah upaya memberi nilai terhadap kegiatan belajar-mengajar yang dilakukan oleh siswa dan guru dalam mencapai tujuan-tujuan dalam pengajaran. Dalam penilaian ini dilihat sejauh mana keefektifan dan efisiensinya dalam mencapai tujuan pengajaran atau perubahan tingkah laku siswa (Sudjana. 2012:3). Untuk mencapai hasil belajar berupa prestasi akademik, toleransi, menerima keragaman, dan pengembangan keterampilan sosial maka dibutuhkan model pembelajaran kooperatif.
Pada pembahasan sistem reproduksi mengandung materi yang erat kaitannya dengan kehidupan sehari-hari, sehingga diperlukan suatu pendekatan pembelajaran yang benar-benar membuat siswa mampu memahami konsep dan mengaplikasikanya dalam kehidupan sehari-hari dan diterapkan dalam model pembelajaran everyone is a teacher here sejauh mana pengaruh hasil belajar siswa yang diterapkan dalam model tersebut. Dalam sistem reproduksi manusia terdapat proses yang meliputi: proses pembentukan sperma (spermatogenesis); pembentukan sel telur (oogenesis); siklus menstruasi; serta proses kehamilan yang dimulai dari proses pembuahan sampai dengan terjadinya kelahiran. Model pembelajaran everyone is a teacher here perlu diterapkan untuk pembelajaran pada materi pokok sistem reproduksi.

\section{Tujuan}

Tujuan yang ingin dicapai dalam penelitian ini adalah:

1. Mengetahui terlaksananya model everyone is a teacher here terhadap hasil belajar siswa pada materi pokok sistem reproduksi.

2. Mengetahui hasil belajar siswa pada materi pokok sistem reproduksi dengan menggunakan model everyone is a teacher here.

3. Mengetahui pengaruh model pembelajaran everyone is a teacher here terhadap hasil belajar siswa pada konsep sistem reproduksi.

\section{Kerangka Berpikir}

Pendidikan adalah salah satu bentuk perwujudan kebudayaan manusia yang dinamis dan sarat perkembangan. Oleh karena itu, perubahan atau perkembangan 
pendidikan adalah hal yang memang seharusnya terjadi sejalan dengan perubahan budaya kehidupan. Perubahan dalam arti perbaikan pendidikan pada semua tingkat perlu terus menerus dilakukan sebagai antisipasi kepentingan masa depan (Trianto, 2010:1)

Everyone is a theacher here yaitu model yang dapat digunakan untuk mengetahui hasil belajar siswa dalam proses pembelajaran, dengan model tersebut maka pengaruh model pembelajaran dapat diketahui dengan hasil belajar berupa tes dan pengaruh model yang diterapkanpun dapat diketahui hasilnya dengan hasil belajar yang lebih bagus lagi sebelum dibelajarkan menggunakan model tersebut. Pengaruh hasil belajar siswa sangat baik jika diterapkan dengan model ini dan melatih siswa dalam melakukan mpengamatan, kemampuan menyimpulkan dll.

\section{Metodologi}

a. Metode Penelitian

Metode penelitian yang digunakan dalam penelitian adalah metode quasi eksperimen atau quasi experimental design (Sugiyono, 2013: 114)

\section{b. Desain Penelitian}

Desain eksperimen yang digunakan dalam penelitian ini adalah desain empat yaitu nonequivalent control group pretestposttest. Dengan pola sebagai berikut:

Tabel 1. Desain Penelitian

\begin{tabular}{|c|c|c|c|c|}
\hline $\begin{array}{c}\text { Kelompok } \\
\text { (group) }\end{array}$ & $\begin{array}{c}\text { Tes } \\
\text { Awal } \\
\text { (pre-test) }\end{array}$ & Perlakuan & $\begin{array}{c}\text { Test } \\
\text { Akhir } \\
\text { (treatment) }\end{array}$ & $\begin{array}{c}\text { Gain } \\
\text { (Post- } \\
\text { test) }\end{array}$ \\
\hline Eksperimen & $\mathrm{O}_{1}$ & $\mathrm{X}$ & $\mathrm{O}_{2}$ & $\mathrm{O}_{2}-\mathrm{O}_{1}$ \\
\hline Kontrol & $\mathrm{O}_{3}$ & - & $\mathrm{O}_{4}$ & $\mathrm{O}_{4}-\mathrm{O}_{3}$ \\
\hline
\end{tabular}

(Sugiyono, 2013: 116)
Keterangan :

Eksperimen : (menggunakan model everyone is a teacher here)

Kontrol : (tanpa menggunakan model everyone is a teacher here)

$\mathrm{X}$ :Treatment (dengan menggunakan model everyone is a teacher here)

$\mathrm{O}_{1}$ : Nilai rata-rata pretest kelas eksperimen

$\mathrm{O}_{2}$ : Nilai rata-rata postest kelas eksperimen

$\mathrm{O}_{3}$ : Nilai rata-rata pretest kelas control

$\mathrm{O}_{4}$ : Nilai rata-rata postest kelas control

Desain ini hampir sama dengan pretest postest control group design, hanya pada desain ini kelompok eksperimen maupun kelompok kontrol tidak dipilih secara random. Efek perlakuan dari peneltian ini yaitu membandingkan hasil postes kelas eksperimen dan hasil postes kelas kontrol.

\section{Analisis}

Analisis data yang akan dilakukan untuk menjawab setiap rumusan masalah adalah sebagai berikut:

1. Lembar observasi berbentuk checklist yang menggunakan dua alternatif, yaitu "Ya" jika pernyataan pada lembar observasi tersebut dapat terlaksana dan "Tidak" jika pernyataan pada lembar observasi tersebut tidak dapat terlaksana.

2. Mengolah hasil tes akhir siswa pada kelas everyone is a teacher here da kelas kontrol. dapat diuji dengan teknik statistik dengan syarat data yang diolah normal dan homogen.

3. Mengetahui pengaruh positif terhadap hasil belajar siswa dengan mengetahui perhitungan uji hipotesis dengan kriteria $\mathrm{T}_{\text {hitung }}>\mathrm{T}_{\text {tabel, }}$ maka Ho ditolak dan Ha diterima pada perhitungan Analisis Uji Hipotesis Uji t.

1) Uji Normalitas 
Uji normalitas dilakukan menggunakan rumus chi Kuadrat $\left(\mathrm{X}^{2}\right)$. Berdasarkan analisis uji normalitas, dapat dilihat pada tabel 2 berikut.

Tabel 2. Hasil Analisis Uji Normalitas

\begin{tabular}{|c|c|c|}
\hline $\begin{array}{c}\text { Harga yang } \\
\text { dicari }\end{array}$ & $\begin{array}{c}\text { Kelas } \\
\text { Eksperimen }\end{array}$ & $\begin{array}{c}\text { Kelas } \\
\text { Kontrol }\end{array}$ \\
\hline Rata-rata (x) & 75,87 & 69 \\
\hline $\begin{array}{c}\text { Standar deviasi } \\
\text { (sd) }\end{array}$ & 12,49 & 11,46 \\
\hline$X_{\text {hitung }}^{2}$ & 4,82 & 7,34 \\
\hline $\begin{array}{c}\text { Derajat } \\
\text { Kebebasan } \\
\text { (dk) }\end{array}$ & 3 & 7,815 \\
\hline $\begin{array}{c}X^{2} \text { tabel } \\
\text { Taraf } \\
\text { signifikansi }\end{array}$ & $5 \%$ & $5 \%$ \\
\hline Keterangan & Normal & Normal \\
\hline
\end{tabular}

Dari tabel 2.7 dapat dilihat bahwa nilai chi kuadrat hitung ( $X^{2}$ hitung) kelas eksperimen < chi kuadrat tabel $\left(X^{2}\right.$ tabel), maka berdistribusi Normal. Sedangkan $\left(X^{2}\right.$ hitung) kelas kontrol < chi kuadrat tabel $\left(X^{2}\right.$ tabel berdistribusi Normal pada taraf signifikansi $5 \%$.

\section{2) Uji Homogenitas}

Setelah diketahui data berdistribusi normal atau tidak, maka selanjutnya uji homogenitas. Dari tabel 3 diketahui $F$ hitung sebesar 1,18 sedangkan F tabel sebesar 1,78. Kriteria pengujiannya adalah data homogen apabila $F$ hitung $<F$ tabel, maka kedua data gain kelas eksperimen dan kontrol adalah Homogen.
Tabel 3. Hasil Analisis Uji Homogenitas

\begin{tabular}{|c|c|}
\hline Harga yang dicari & Hasil \\
\hline Variansi besar $(\mathrm{Vb})$ & 156 \\
\hline Variansi kecil $(\mathrm{Vk})$ & 131.33 \\
\hline$F_{\text {hitung }}$ & 1,18 \\
\hline$F_{\text {tabel }}$ & 1,78 \\
\hline
\end{tabular}

3) Uji Hipotesis

Setelah diketahui normalitas dan homogenitasnya, maka dilanjutkan dengan pengujian hipotesis. Karena data berdistribusi normal, maka pengujian hipotesis dilakukan.

Tabel 4. Hasil Analisis Uji T

\begin{tabular}{|c|c|c|c|c|}
\hline \multirow[b]{2}{*}{ Kelas } & \multicolumn{2}{|c|}{ Nilai } & \multirow{2}{*}{$\begin{array}{l}\text { Taraf } \\
\text { Signif } \\
\text { ikansi }\end{array}$} & \multirow[b]{2}{*}{ Ket } \\
\hline & $\begin{array}{c}\mathbf{T} \\
\text { hitung }\end{array}$ & $\begin{array}{c}\mathbf{T} \\
\text { tabel }\end{array}$ & & \\
\hline $\begin{array}{c}\text { XI } \\
\text { IPA } \\
2\end{array}$ & 2,38 & 1,67 & $5 \%$ & $\begin{array}{c}\mathrm{H}_{\mathrm{o}} \text { ditolak } \\
\text { dan } \\
\mathrm{H}_{\mathrm{a}} \text { diterima }\end{array}$ \\
\hline
\end{tabular}

Dengan menggunakan taraf kesalahan 5\%, maka harga $\mathrm{T}$ tabelnya adalah 1,67. Pengujiannya dengan kriteria hipotesis jika $T_{\text {hitung }}>T_{\text {tabel, maka Ho }}$ ditolak dan $\mathrm{Ha}$ diterima. Berdasarkan perhitungan diperolah $T_{\text {hitung }}=2,38$ dan $T_{\text {tabel }}=1,67$ yang berarti Ho ditolak dan Ha diterima. Jadi terdapat pengaruh yang positif dan signifikan pada pembelajaran yang menggunakan model everyone is a teacher here. Hal ini berarti model pembelajaran everyone is a teacher here berpengaruh positif dan signifikan terhadap hasil belajar siswa.

1. Untuk Menganalisis Lembar Observasi digunakan tahapan sebagai berikut: 
a. Menghitung Ketelaksanaan lembar observasi dengan rumus sebagai berikut:

$$
\mathrm{NP}=\frac{R}{S M} \times 100 \%
$$

Keterangan :

NP : Nilai persen keterlaksanaan yang dicari atau yang diharapkan

$\mathrm{R}$ : Jumlah skor yang diperoleh

SM : Skor maksimum ideal

Tabel 5 Kriteria Tingkat Keterlaksanaan

\begin{tabular}{|c|c|c|c|}
\hline $\begin{array}{c}\text { Tingkat } \\
\text { Keterlaksan } \\
\text { aan }\end{array}$ & $\begin{array}{c}\text { Nilai } \\
\text { Huru } \\
\mathbf{f}\end{array}$ & Bobot & Ket \\
\hline $86-100 \%$ & $\mathrm{~A}$ & 4 & $\begin{array}{c}\text { Sangat } \\
\text { baik }\end{array}$ \\
\hline $76-85 \%$ & $\mathrm{~B}$ & 3 & Baik \\
\hline $60-75 \%$ & $\mathrm{C}$ & 2 & Cukup \\
\hline $55-59 \%$ & $\mathrm{D}$ & 1 & Kurang \\
\hline$<54 \%$ & $\mathrm{E}$ & 0 & $\begin{array}{c}\text { Kurang } \\
\text { sekali }\end{array}$ \\
\hline
\end{tabular}

(Purwanto, 2008 : 102)

\section{Hasil Dan Pembahasan}

a. Analisis Hasil Observasi Proses Pembelajaran Model everyone is a teacher here Pada Materi Pokok Sistem Reproduksi.

Keterlaksanaan proses pembelajaran aktivitas guru dengan menggunakan model everyone is a teacher here dapat dilihat pada tabel 6 dibawah ini:

Tabel 6. Rekapitulasi Data Hasil Observasi Aktivitas Pembelajaran Guru dan Siswa

\begin{tabular}{|c|c|c|c|c|}
\hline \multirow[b]{2}{*}{ No } & \multicolumn{4}{|c|}{ Aktivitas Pembelajaran } \\
\hline & Guru & $\begin{array}{c}\text { Reliabili } \\
\text { tas }\end{array}$ & Siswa & \begin{tabular}{|c} 
Reliabi \\
litas
\end{tabular} \\
\hline & $\begin{array}{l}\text { Skor } 1 \\
\text { Observer } \\
1: 18 \\
\text { Observer } \\
2: 18\end{array}$ & $\begin{array}{l}94 \% \\
\text { (Baik) }\end{array}$ & $\begin{array}{l}. \text { Skor } 1 \\
\text { Observer } \\
1: 18 \\
\text { Observer } \\
2: 18\end{array}$ & $\begin{array}{l}94 \% \\
\text { (Baik) }\end{array}$ \\
\hline 1. & $\begin{array}{l}\text { Skor } 2 \\
\text { Observer } \\
1: 19 \\
\text { Observer } \\
2: 19\end{array}$ & $\begin{array}{l}95 \% \\
\text { (Baik) }\end{array}$ & $\begin{array}{l}. \text { Skor } 2 \\
\text { Observer } \\
1: 19 \\
\text { Observer } \\
2: 19\end{array}$ & $\begin{array}{l}95 \% \\
\text { (Baik) }\end{array}$ \\
\hline
\end{tabular}

Berdasarkan tabel diatas Persentase aktivitas pembelajaran guru pada pertemuan pertama sampai akhir yaitu 95\% dan termasuk kategori baik. Akan tetapi masih ada beberapa tahapan dalam pembelajaran yang tidak terlaksana (5\%), yaitu pada kegiatan inti ada 1 yang tidak terlaksana dan satu tahapan pada kegiatan awal. Tahapan tersebut adalah guru tidak mengucapkan salam, memerintahhkan siswa untuk berdo'a dan mengecek kehadiran, dalam artian guru tidak memeriksa prosedur yang harus dilakukan dalam pembelajaran dan lainnya.

Berdasarkan hasil observasi ada faktor yang menyebabkan satu tahapan proses pembelajaran guru tidak terlaksana pada pertemuan pertama, yaitu tidak mengucapkan salam, memerintahhkan siswa untuk berdo'a dan mengecek kehadiran. Sehingga ada beberapa tahapaan proses pembelajaran guru tidak terlaksana. Persentase keterlaksanaan aktivitas pembelajaran guru pada pertemuan pertama digambarkan dalam diagram berikut ini. 


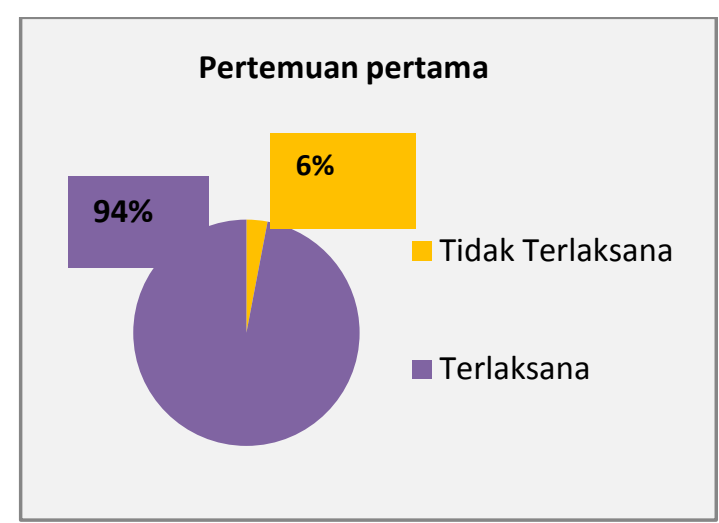

Gambar 1. Diagram Aktivitas Pembelajaran Guru Pertemuan Pertama

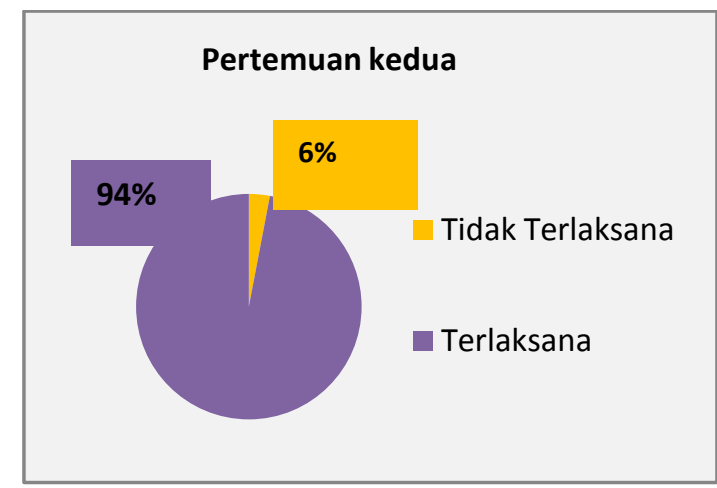

Gambar 2. Diagram Aktivitas Pembelajaran Guru Pertemuan Kedua

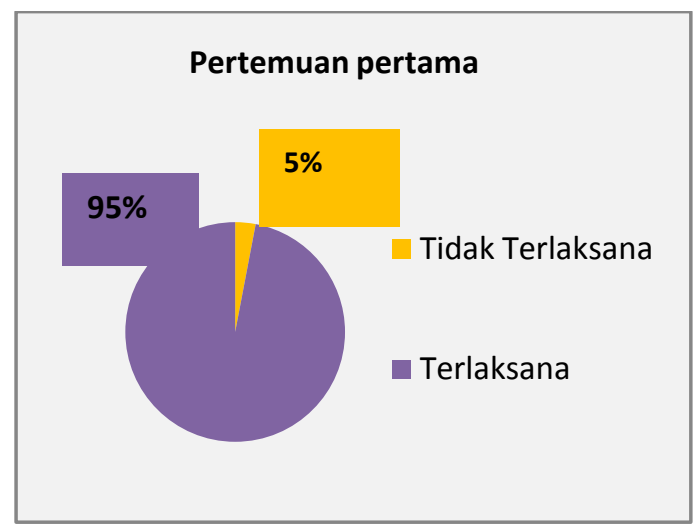

Gambar 3. Diagram Aktivitas Pembelajaran Siswa Pertemuan Pertama

Analisis hasil observasi aktivitas proses pembelajaran guru dan siswa diatas dalam setiap pertemuan dapat disimpulkan semua terlaksanan dengan baik. Keterlaksanaan proses pembelajaran ini merupakan hal utama yang didambakan dalam melaksanakan proses pembelajaran berlangsung, salah satunya dengan menggunakan model pembelajaran yang tepat. Model pembelajaran perlu difahami guru agar dapat melaksanakan pembelajaran secara efektif dalam meningkatkan hasil pembelajaran pada pendidikan.

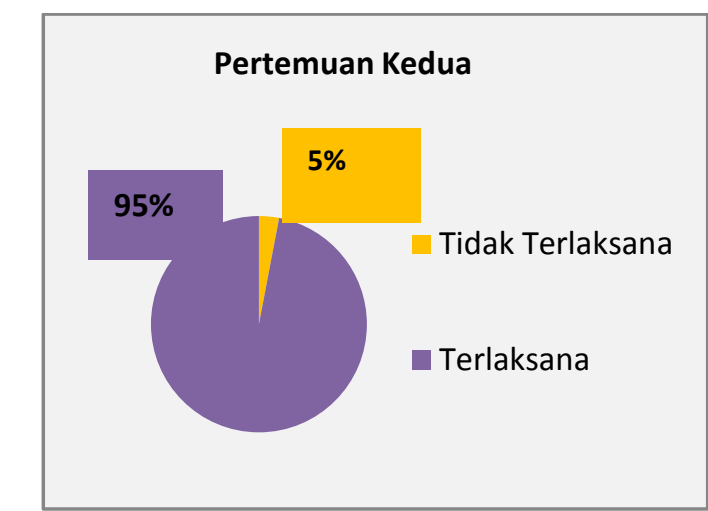

Gambar 4. Diagram Aktivitas Pembelajaran Siswa Pertemuan Kedua

Menurut (Sanjaya. 2009:281) peran guru sebagai sumber belajar, merupakan peran yang sangat penting. Peran sebagai sumber belajar berkaitan erat dengan penguasaan materi pelajaran. Kita bisa melihat baik atau tidaknya seorang guru hanya dari penguasaan materi pelajaran.

\section{b. Analisis tes hasil belajar (posttest)}

Hasil belajar siswa dengan menggunakan model everyone is a teacher here. Untuk mengetahui hasil belajar siswa dapat dilihat pada Gambar 5 dibawah ini.

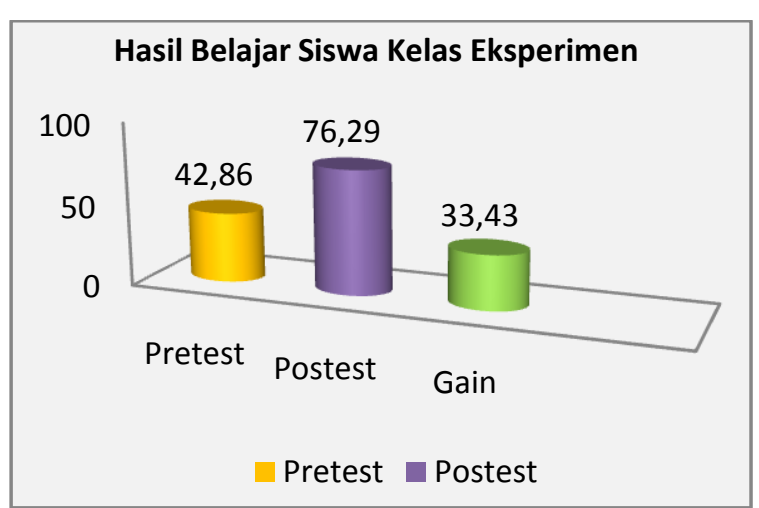


Gambar 5. Diagram Hasil Belajar siswa kelas Eksperimen

Dari hasil belajar dengan menggunakan model everyone is a teacher here dapat diketahui dengan perolehan hasil belajar siswa kelas eksperimen yaitu skor pretest 42,86 dan skor postest 76,29 dan gain 33,43. Sebagai pembanding maka data dari skor pretest dan skor postet pada kelas kontrol dengan menggunakan model yang setara dengan model pada kelas eksperimen yaitu model Listening team. Dengan melihat tabel 7 dibawah ini.

Tabel 7 Hasil belajar kelas kontrol dengan model yang setara dengan kelas eksperimen "Listening Team"

\begin{tabular}{|c|c|c|c|}
\hline \multirow{2}{*}{ Kriteria } & \multicolumn{3}{|c|}{ Rata-rata } \\
\cline { 2 - 3 } & Pretest & Posttest & $\begin{array}{c}\text { Gain } \\
\left(\mathbf{O}^{2}-\mathbf{O}^{\mathbf{1}}\right)\end{array}$ \\
\hline $\begin{array}{c}\text { Kelas } \\
\text { Kontrol }\end{array}$ & 42,57 & 69,43 & 26,86 \\
\hline Kategori & Kurang & Baik & \\
\hline
\end{tabular}

Dari hasil perhitungan hasil belajar kelas eksperimen dengan menggunakan model everyone is a teacher here dan kelas kontrol dengan menggunakan model yang setara yaitu Listening team dapat dilihat pada gambar 6. dibawah ini.

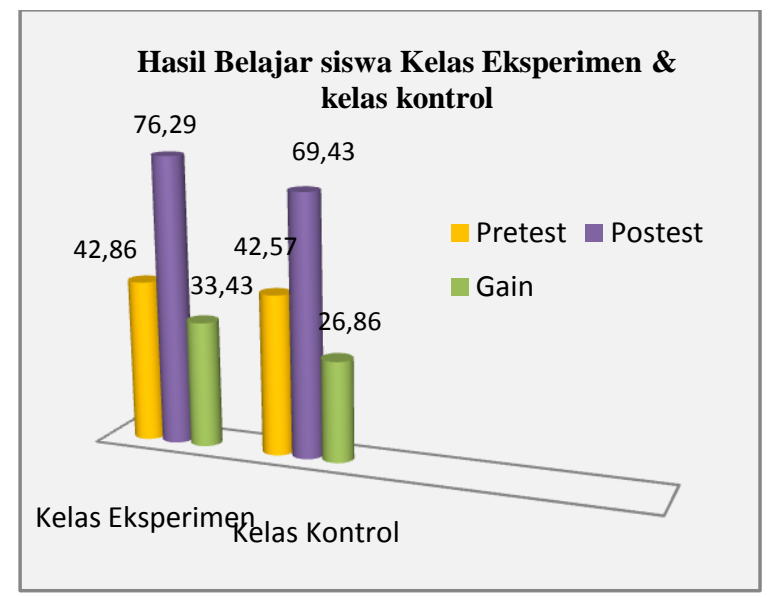

Gambar 6. Diagram Hasil belajar siswa Kelas Eksperimen dan Kelas Kontrol c. Pengaruh Model pembelajaran everyone is a teacher here terhadap hasil belajar Siswa.

Pengaruh hasil belajar siswa dapat dilhat pada tabel 8 dibawah ini.

Tabel. 8 Rekapitulasi Hasil Perhitungan Uji Hipotesis Uji T

\begin{tabular}{|c|c|c|c|c|}
\hline \multirow[b]{2}{*}{ Kelas } & \multicolumn{2}{|c|}{ Nilai } & \multirow{2}{*}{$\begin{array}{c}\text { Taraf } \\
\text { Signifi } \\
\text { kansi }\end{array}$} & \multirow[b]{2}{*}{ Ket } \\
\hline & $\begin{array}{c}\mathbf{T} \\
\text { hitung }\end{array}$ & $\begin{array}{c}\mathbf{T} \\
\text { tabel }\end{array}$ & & \\
\hline $\begin{array}{c}\text { XI } \\
\text { IPA } \\
2\end{array}$ & 2,38 & 1,67 & $5 \%$ & $\begin{array}{c}\mathrm{H}_{\mathrm{o}} \text { ditolak } \\
\text { dan } \\
\mathrm{H}_{\mathrm{a}} \text { diterima }\end{array}$ \\
\hline
\end{tabular}

Dengan menggunakan taraf kesalahan 5\%, maka harga $\mathrm{T}$ tabelnya adalah 1,67. Pengujiannya dengan kriteria

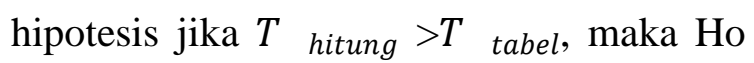
ditolak dan $\mathrm{Ha}$ diterima. Berdasarkan perhitungan diperolah $T$ hitung $=2,38$ dan $T_{\text {tabel }}=1,67$ yang berarti Ho ditolak. Jadi terdapat pengaruh yang positif dan signifikan pada pembelajaran yang menggunakan model everyone is a teacher here. Hal ini berarti model pembelajaran everyone is a teacher here berpengaruh positif dan signifikan terhadap hasil belajar siswa.

Penelitian ini diperkuat oleh beberapa penelitian serupa seperti yang dilakukan oleh Pratomo (2012) yang menyebutkan bahwa dapat diinterpresentasikan sebagai berikut: Ho ditolak - Ha diterima artinya ada perbedaan yang signifikan antara rata-rata hasil belajar biologi ranah kognitif berdasarkan model pembelajaran (kelompok kontrol dengan model pembelajaran konvensional dan kelompok eksperimen dengan model Everyone is a Teacher Here) sehingga diintepresikan penerapan model Everyone 
is a Teacher Here berpengaruh terhadap hasil belajar biologi ranah kognitif.

Keberhasilan penerapan model pembelajaran kooperatif tipe everyone is a teacher here dalam membantu siswa memahami materi sistem reproduksi tidak terlepas dari beberapa faktor. Syah (2005:132) mengemukakan bahwa faktorfaktor yang dapat mempengaruhi belajar siswa adalah faktor internal (psikologis), faktor eksternal (lingkungan) dan faktor pendekatan belajar.

Menurut Hidayat (2010:229) penilaian hasil pembelajaran, penilaian dilakukan oleh guru terhadap hasil pembelajaran untuk mengukur tingkat pencapaian kompetensi peserta didik, serta digunakan sebagai bahan penyusunan laporan kemajuan hasil belajar, dan memperbaiki proses pembelajaran. Penilaian dilakukan secara konsisten, sistematik, dan terprogram dengan menggunakan tesdan notes dalam bentuk tertulis atau lisan, pengamatan kinerja, pengukuran sikap, penilaian hasil karya berupa tugas, proyek dan/atau produk, portofolio, dan penilaian diri. Penilaian hasil belajar menggunakan standar penilaian pendidikan dan panduan penilaian kelompok mata pelajaran.

\section{Simpulan}

Hasil penelitian tentang penerapan model pembelajaran kooperatif tipe everyone is a teacher here terhadap hasil belajar siswa SMA kelas XI di SMA Negeri Jatinangor pada materi pokok sistem reproduksi, dapat ditarik kesimpulan sebagai berikut:

1. Keterlaksanaan model pembelajaran pada materi sistem reproduksi dengan menggunakan model everyone is a teacher here pada aktivitas pembelajaran guru dan siswa rata-rata 95\%. dapat terlaksana dengan baik.

2. Hasil belajar siswa pada konsep sistem reproduksi dengan penerapan model everyone is a teacher here pada kelas eksperimen diperoleh hasil pretest 42,86 postest 76,29 (Baik) dan Gain 33,43 . Hasil belajar kelas eksperimen tersebut berbeda dengan hasil belajar kelas kontrol yang memperoleh nilai rata-rata pretes 42,57 postest 69,43 (Cukup) dan Gain 26,86.

3. Pada perhitungan uji hipotesis melalui uji T pada taraf signifikan 5\% didapat hasil Thitung 2,38 dan Ttabel 1,67 atau Thitung > Ttabel maka data tersebut dapat disimpulkan bahwa pengaruh model pembelajaran everyone is a teacher here berpengaruh positif terhadap hasil belajar siswa pada materi pokok sistem reproduksi.

\section{Daftar Pustaka}

AMK, Syarifuddin. 2006. Anatomi dan Fisiologi untuk mahasiswa keperawatan. Jakarta: Buku Kedokteran (EGC).

Arikunto, Suharsimi. 2009. Dasar-Dasar Evaluasi Pendidikan. Jakarta: Bumi Aksara

Arikunto, Suharsimi. 2010. Prosedur Penelitian Suatu Pendekatan Praktik. Jakarta: Rineka Cipta.

Aunurrahman. 2011. Belajar dan Pembelajaran. Bandung: Alfabeta

Djamarah, B. Syaiful, dan Aswan Zain.2000. Strategi belajar mengajar. Jakarta: Rineka cipta.

Hasan Iqbal. 2009. Analisis data penelitian dengan statistik. Jakarta: PT. Bumi Aksara.

Herlanti ,yanti. 2006 . Tanya jawab seputar pendidikan sain. Jakarta: UIN Syarif Hidayatullah. 
Hidayat, Ara. 2010. Pengelolaan pendidikan, konsep,prinsip dan aplikasi dalam mengelola sekolah dan madrasah. Bandung: PUSTAKA EDUCA

Hisyam Zaini dkk. 2008. Strategi pembelajaran aktif. Yogyakarta: PT. Pustaka Insan Mandiri

H. Fadli Abdul Rohman. 2006. Al- Qur'an. Qs Al-Alaq:ayat 1-5. Surabaya: Penerbit PUSTAKA AGUNG HARAPAN. (Dikutip Tanggal 22 Februari 2014).

Isjoni, 2010. Cooperative Learning, Efektifitas Pembelajaran Kelompok. Bandung: Alfabeta

Jihad dan Haris. 2009. Evaluasi pembelajaran. yogyakarta: multi pressido

Karmana, oman. 2008. Cerdas belajar biologi. Bandung: Grafindo Media Pratama

Pratomo,dkk. 2012. Hasil belajar biologi ranah kognitif ditinjau dari model Everyone is a teacher here dan minat belajar siswa kelas IX di SMA Negeri Sukoharjo. Semarang: Universitas Negeri Semarang UNS.

Purwanto, M. Ngalim. 2008. Prinsipprinsip dan Teknik Evaluasi Pengajaran. Bandung: PT Remaja Rosdakarya.

Reece- Mitchel, Campbell. 2004. BIOLOGI CAMPBELL Edisi Kelima- Jilid 3. Jakarta: Erlanggam

Ruswandi, Uus, dkk. 2011. Landasan Pendidikan, Bandung: Penerbit CV.INSAN MANDIRI.

Sanjaya, Wina. 2009. Kurikulum dan pembelajaran. Teori dan praktik pengembangan kurikulum tingkat satuan pendidikan (KTSP). Jakarta: Prenada Media Group.

Sardiman A.M. 2012. Interaksi \& Motivasi BELAJAR MENGAJAR. Jakarta: PT RajaGrafindo Persada

Subana. Dkk. 2000. Statistik pendidikan. Bandung: CV.PUSTAKA SETIA
Sudjana, Nana. 2010. Dasar-Dasar Proses Belajar Mengajar. Bandung: SINAR BARU ALGENSINDO OFFSET

Sudjana, Nana. 2012. Penilaian hasil proses belajar mengajar. Bandung: PT.REMAJA ROSDAKARYA.

Sugiyono.2010. Statistika untuk Penelitian. Bandung: Alfabeta.

Sugiyono. 2013. METODE PENELITIAN PENDIDIKAN Pendekatan Kuantitatif, Kualitatif dan $R \& D$. Bandung: Alfabeta.

Suprijono, Agus. 2010. Cooperative Learning "Teori dan Aplikasi Paikem. Yogyakarta:PUSTAKA PELAJAR.

Suripto. Tanpa Tahun. STRUKTUR HEWAN. BANDUNG: ITB

Susilawati, wati. 2013. Belajar dan pembelajaran matemaika. Bandung: CV. INSAN MANDIRI

Syah, Muhibbin. 2008.Psikologi Pendidikan dengan pendekatan Baru. Bandung: Remaja Rosda Karya.

Syamsuri, istamar dkk. 2006. BIOLOGIUntuk SMA Kelas XI. Jakarta: ERLANGGA

Tirtarahardja, Umar. Dkk. 2005. Pengantar pendidikan. Jakarta: PT.RINEKA CIPTA.

Trianto. 2010. Mendesain model pembelajaran Inovatif Progresif. Jakarta: PRENADA MEDIA GROUP

Trianto. 2011. Mendesain Model Pembelajaran Inovatif-Progresif: Konsep, Landasan, dan Implementasi pada Kurikulum Tingkat Satuan Pendidikan (KTSP). Jakarta: Kencana Prenada Media Group.

Undang-Undang Republik Indonesia No. 20 Tahun 2003 Tentang Sistem Pendidikan Nasional. Jakarta: BP. PANCA USAHA.

Yatim, Wildan. 1994. REPRODUKSI \& EMBRYOLOGI. Untuk Mahasiswa Biologi \& Kedokteran. Bandung: TARSITO 
Agustus 2015, Vol. 5, No. 1 